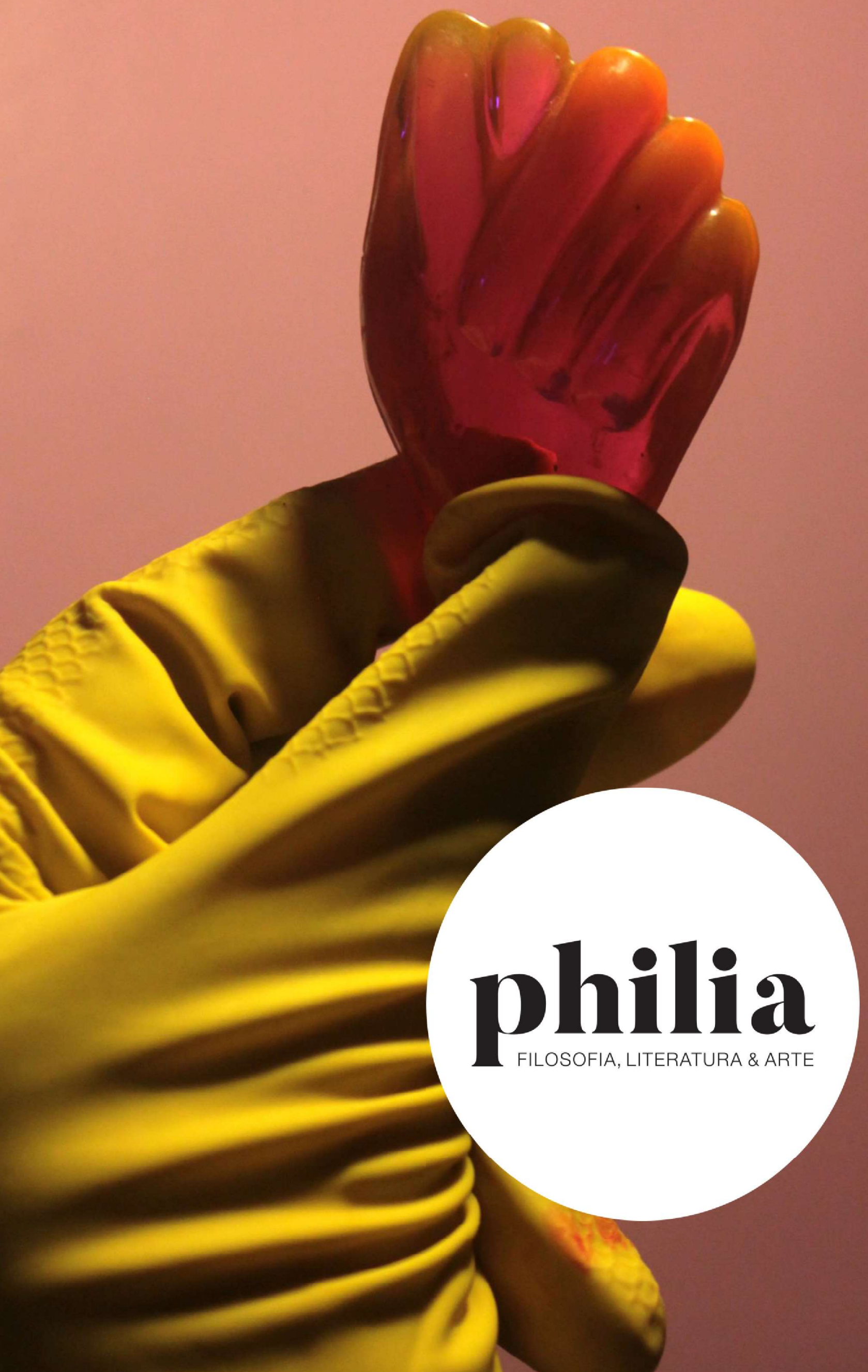




\section{> Volume 1, Número 2}

Outubro de 2019

ISSN 2596-0911

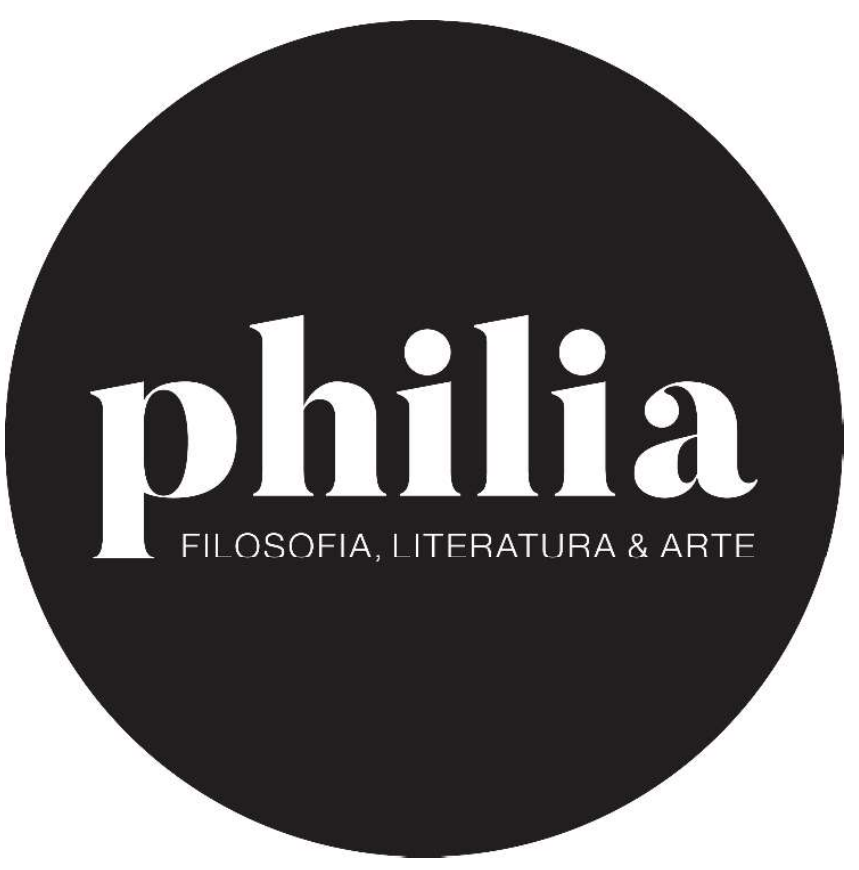




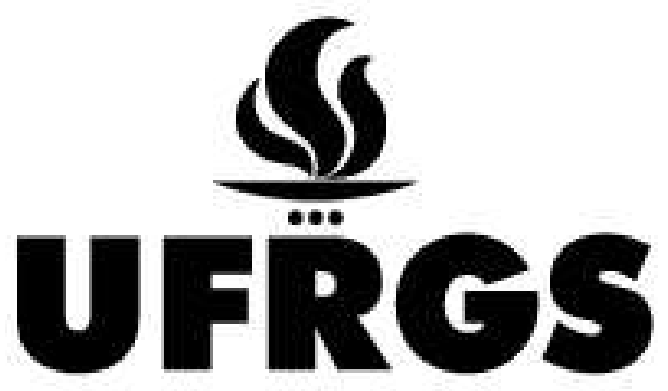

UNIVERSIDADE FEDERAL DO RIO GRANDE DO SUL 


\section{$>$ UNIVERSIDADE FEDERAL DO RIO} GRANDE DO SUL | UFRGS

Avenida Paulo Gama, 110.

Bairro Farroupilha, Porto Alegre, RS. CEP 90040-060

Reitor

Rui Vicente Oppermann

Coordenação do Programa de Pós-Graduação em Filosofia

Alfredo Carlos Storck

Coordenação do Programa de Pós-Graduação em Letras

Antõnio Marcos Vieira Sanseverino

Coordenação do Programa de Pós-Graduação em Artes Visuais

Paulo Antonio de Menezes Pereira da Silveira

> REVISTA PHILIA | FILOSOFIA,

LITERATURA \& ARTE

Volume 1, Número 2

ISSN 2596-0911

Periodicidade Semestral

Editores Seniores

Kathrin Holzermayr Rosenfield

Alexandre Santos

Editor | Filosofia

Guilherme Mautone

Editores | Literatura

Davi Alexandre Tomm

Lauro Iglesias Quadrado

Editora | Artes

Paula Trusz

Coordenadora Editorial

Patrícia Cristine Hoff

Assistentes Editoriais | Filosofia

Liana Schedler

André Luís de Souza Lima

Assistentes Editoriais | Literatura

Lis Yana De Lima Martinez

Caroline Navarrina de Moura

Assistentes Editoriais | Arte

Luciane Bucksdricker

Isadora Buzo Mattiolli

\section{Conselho Editorial}

Aaron Shaheen, The University of Tennessee at Chattanooga, EUA

Antônio Eduardo Soares Laranjeira, UFBA

Carla Milani Damião, UFG

Daniela Queiroz Campos, UFSC

Glória Ferreira, UFRJ

Eduardo Ferreira Veras, UFRGS

Hans Ulrich Gumbrecht, Stanford University, EUA

Jed Rasula, University of Georgia, EUA

John Hamilton, Harvard University, EUA

Jônadas Techio, UFRGS

Laurence Hemming, Lancaster University, UK

Márcio Orlando Seligmann-Silva, Unicamp

Marilice Villeroy Corona, UFRGS

Neil Hertz, Johns Hopkins University, EUA

Pedro Mandagará, UnB

Rafael Lopes Azize, UFB

Simone Homem de Mello, Casa Guilherme de Almeida, São Paulo

Tadeu Capistrano, UFRJ

Ted Nannicelli, University of Queensland, AU

Virgínia de Araújo Figueiredo, UFMG

\section{Projeto Gráfico}

Guilherme Mautone

Diagramação

Guilherme Mautone

Imagem da Capa

Letícia Lopes, Elogio ao Mistério, 2019

\section{Revisão}

Adriana Viegas Caterina, Cláudia Fernanda Pavan, Denise de Quintana Estacio, Felipe Pergher, Fernanda Nunes Menegotto,

Francelle Machado Viegas, Helen Ribeiro

Nunes, Joanne de Bittencourt Fraga,

Leonardo Foschiera de Mesquita, Lucas

Meireles Tcacenco, Sara Luiza Hoff.

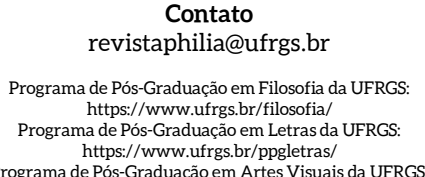




\section{> Sumário \\ $>$ Table of Contents}

\section{EDITORIAL | EDITORS FOREWORD}

Ano de cães danados

A stray-dog year

> por Davi Alexandre Tomm, Guilherme Mautone, Lauro Iglesias Quadrado,

Patrícia Cristine Hoff, Paula Trusz ............................................................................................... ix

\section{ARTIGOS $\mid$ PAPERS}

Uma Sutil Diferença: narrativas carcerárias em videoclipes de rappers brasileiros apenados e não apenados (1997 - 2000)

A Slight Difference: prison narratives in sentenced and unsentenced Brazilian rappers' videoclips (1997 - 2000)

$>$ por Alisson Cruz Soledade

Estudos Culturais, Estudos Literários e Discussão Pós-Colonial: refletindo sobre o pensamento crítico

Cultural Studies, Literary Studies and Post-Colonial Discussion: reflecting upon critical thinking

$>$ por Alisson Preto Souza

De Paisagens Escritas e Paisagens Pintadas: vínculos conceituais entre a pintura de Hipólito Caron e o romance Inocência de Alfredo Taunay

From Written Landscapes And Painted Landscapes: conceptual bonds between Hipólito Caron's painting and Alfredo Taunay's novel Inocência

$>$ por Ana Carla de Brito

Anotações sobre a centralidade do artista na história da arte

Notes on artist's centrality in the history of art

$>$ por Angela Brandão

Sobre lampejos em tempos de chumbo, ou, por uma comunidade de vaga-lumes, ou, o que pode a arte?

About glimpses in ages of lead or for a community of fireflies or what can art do?

$>$ por Antonio Carlos Sobrinho 
Oralidade, Escrita e Estilo em Platão e Montaigne

Orality, Writing and Style in Plato and Montaigne

$>$ por Bruno Alonso

Existential isolation in Whisky (2004), reading uruguayan cinema beyond the concept of smallcinema

Isolamento existencial em Whisky (2004), lendo cinema uruguaio para além do conceito de smallcinema

$>$ por Cesar Lopes Gemelli

A ironia no trabalho fotográfico de Carlos Pasquetti

Irony in the photographic work of Carlos Pasquetti

$>$ por Claudio Barcellos Jansen Ferreira

Approaching Fäerie: a study of J. R. R. Tolkien's on fairy-stories

Abordando Fäerie: Um estudo sobre histórias de fadas de J. R. R. Tolkien

> por Fabian Quevedo da Rocha

Leviatã: o boato como elemento intersticial entre objeto e sujeito

Leviathan: The rumor as interstitial element between object and subject

$>$ por Fercho Marquéz

Literature From The Margins: a study on the relevance of zines

Literatura das Margens: Um estudo sobre a relevância dos zines

> por Fernanda Martinez Tarran e Nathalia Rodrigues de Carvalho

A vida de Gulliver entre os Houyhnhnms e a visão de Paulo: ser um Yahoo (Humano) é ter um espinho na carne?

Gulliver's Life Among The Houyhnhnms and Paul's Vision: Does being a Yahoo (human) mean having a thorn in the flesh?

> por Fernando Bruno Antonelli Molina Benites e Mauricio Cesar Menon ..... 271

Gender \& Perspective in Scarlet Street

Gênero \& Perspectiva em Scarlet Street

$>$ por Fernando Valenzuela Carlucci 
A concepção relacional do poder em Foucault e a omissão da valoração ética

The relational conception of power on Foucault and the omission of ethical valoration

> por Igor Corrêa de Barros

Notas sobre a influência platônica em Michelangelo

Some remarks about the platonic influence in Michelangelo

$>$ por Laura Elizia Haubert

A escuta do amor, de orelha a orelha

The listening of love, from ear to ear

$>$ por Lucas Cyrino

Blank Verse: a história e as histórias de William Shakespeare traduzidas em websérie

Blank Verse: William Shakespeare's stories and history translated to a web series

> por Manoela Sarubbi Henares Figueiredo 395

Macunaíma: diálogo com o romantismo a partir da paródia de Peri

Macunaima: A dialogue with the romanticism movement - the Peri's parody

> por Maria Júlia Pereira

A dialética da música em Dona Flor e seus dois maridos

The dialectic of music in Dona Flor e seus dois maridos

$>$ por Paulo Augusto Nedel

O conceito de inautenticidade no pensamento heideggeriano de Ser e tempo

The concept of inauthenticity in the heideggerian thought of Being and time

> por Rafael Ribeiro Almeida e Rogério Tolfo 461

A Prosa Poética de Kate Chopin: imagens líricas da noite e o descompasso do homem na orquestra de Deus

Kate Chopin's Prose Poetry: lyrical images of the night and the mismatch of the man in God's orchestra

$>$ por Rosemary Elza Finatti 
Um estudo sobre três premissas do argumento ateu na peça O berço do herói, de Dias Gomes

Three premises of the atheist argument in Dias Gomes's play O berço do herói: A study > por Ricardo Cortez Lopes e Yana de Lima Martinez 505

Cinema e fotografia: as técnicas e suas ambiguidades em Benjamin, Flusser e Agamben

Cinema and photography: the techniques and their ambiguities in Benjamin, Flusser and Agamben

> por Sônia Campaner Miguel Ferrari 526

O domínio da arte no pensamento de Hannah Arendt

The realm of art in Hannah Arendt's thought

$>$ por Thiago de Castro Leite 548

\section{RESENHA | REVIEW}

Helena é Tróia: ou As Helenas de Troia, NY, de Bernadette Mayer

Helen Is Troy: or The Helens of Troy, New York, of Bernadette Mayer

> por Renan Augusto Ferreira Bolognin e Nicolas Ferreira Neves Jacintho .... 565

\section{TRADUÇÕES | TRANSLATIONS}

Três contos de morte de Horacio Quiroga

Three tales of death by Horacio Quiroga

$>$ por Juan Carlos Acosta 575

Cinco ensaios de The Philosophy of Style, de Herbert Spencer

Five essays of The Philosophy of Style, from Herbert Spencer

> por Thaís Fernandes dos Santos 596

\section{ENSAIO VISUAL | VISUAL ESSAY}

Elogio ao Mistério: revelações de atelier

Ode to mistery: revelations from the studio

$>$ por Letícia Lopes 